\title{
A Study of Bait Selection in Small African Rodents
}

\author{
P. A. ANADU
}

Aradu P. A., 1979: A study of bait selection in small African rodents. Acta theriol., 24, 36: 501-511 [With 6 Tables \& 1 Fig.].

The results of assessing the effectiveness of baited and unbaited traps, and of several locally available foodstuffs, for the capture of small Nigerian rodents are described. Baited traps caught significantly more mice than unbaited traps. Seven baits, selected after a preliminary trial of 15 baits, were tested on a grassland community of small rodents, and it was found that the most frequently trapped species, Tatera valida, Praomys (Myomys) daltoni and Mus minutoides did not show a clear-cut preference for any of them. When five of these baits were tested on a forest community, it was found that maize meal/peanut butter and fresh coconut were the most effective baits for the capture of the commonest species, Praomys tullbergi. The implications of these findings are discussed and it is suggested that fresh coconut could be a suitable »all purpose « bait for the capture of both forest and savanna rodents.

[Dept. Zool., Univ. Ibadan, Ibadan, Nigeria]

\section{INTRODUCTION}

The secretive habits of small mammals makes their study by direct observation in the field very difficult, and indeed few such studies have been attempted even for diurnal species (e.g., A d a m s \& D a vi s, 1967). The most practical techniques for the study of their ecology are trapping and radio tracking. Radio tracking has been employed mainly for the study of movements while trapping, which permits closer examination of animals, provides information on reproduction, density, age and sex structure, food habits, condition of health as well as morphometric data. However, it is not always certain that the data obtained by trapping truly reflect the demographic characteristics of the population under study. Wellknown sources of bias include individual differences in trap response, bait effectiveness, trap selection, uncertainty about the area sampled by the traps and competition for traps (analogous to "gear saturation " in fishing).

Numerous suggestions for improving the reliability of trapping data are found in the literature, but these have been proposed largely by North American and European workers. Only a few studies of this nature have been undertaken in tropical Africa (e.g., D el a ny, 1964, 
1971; N e a l \& C o ck, 1969) where the ecology of small mammals has only recently begun to receive serious attention.

This paper presents the results of an attempt to evaluate the role of bait, as well, as the relative efficiency of various local readily available foodstuffs as bait in the capture of mice. Some of the baits tested have been used by previous workers in Africa, while some appear to be new formulations.

Nomenclature for rodents follows Me ester \& Setzer (1971-77)

\section{MATERIALS AND METHODS}

\subsection{The Study Areas}

The study was carried out at two sites in South-western Nigeria, viz; at Aje-Pero $\left(7^{\circ} 54^{\prime} \mathrm{N}, 3^{\circ} 43^{\prime} \mathrm{E}\right)$ near Fashola on the Oyo-Iseyin road, and at the International Institute for Tropical Agriculture (hereafter referred to as the IITA) near the University of Ibadan, Nigeria. The vegetation at Aje-Pero is derived savanna, while at the IITA traps were set inside a forest relic.

\subsection{Baits}

At Aje-Pero 15 baits were tested initially (Table 1). Later (December 1976 to March 1977) the number of baits was reduced to seven. At the IITA only five baits were tested.

All baits were freshly made, and those consisting of two or more substances were mixed into a firm paste. Maize/peanut butter and garri (=cassava meal)! peanut butter baits were made up in the ratio of 2 parts (Maize or garri) : 1 part peanut butter. Peanut butter was made by mixing crushed roaster groundnut seeds with groundnut oil. Mouse cubes were offered uncrushed, and whenever garri was used it was first prepared with hot water ("eba «) before the other ingredients were added.

\subsection{Trapping and Handling of Mice}

At Aje-Pero mice were caught with live traps (Havahart No. 0) set on a rectangular grid. The grid had 10 rows $\times 10$ columns of trapping points set $13.8 \mathrm{~m}$ apart. These trapping points were marked with numbered metal stakes. Traps were placed in groups of four per station in alternate rows of the grid, so that only 50 stations were activated during each visit. At each trap station only three traps were baited, each with a different food substance; the fourth trap was left as a control. Traps were usually set between $1600-1730 \mathrm{hr}$ and checked the next day between $0700-1000 \mathrm{hr}$. Trapping was carried out during fortnightly visits throughout the study, and each visit lasted four days. Traps were prebaited for three nights and set on the fourth.

Upon first capture each mouse was marked for individual recognition by a system of toe clipping and ear punching. Each mouse was released at the site of capture.

From March to July 1976 a different combination of baits was tried each month (See Table 1). During the second phase of the experiment, when the 
number of baits was reduced to seven, all baits (plus control) were presented together every month. The grid was divided into two halves during this period each half containing 25 trap stations. Each half received a different treatment during each visit (e.g. four baited traps per station in one half and three baited traps plus the control in the other half). This arrangement ruled out the effect of bait position. The fortnightly sequence of bait placement was chosen randomly, but the overall result was that every bait appeared at least twice in each half of the grid during this period. The seven baits tested were the top six baits with a success rate of $35 \%$ or more in the preliminary trial (Fig. 1), plus peanut butter. The latter was included because it appeared to have been used successfully elsewhere in Africa (e.g., Hanney, 1965; Happold, 1966; Delany, 1971), and is fairly popular with North American workers.

Table 1

The sequence of bait trials at Aje-Pero (March-July 1976) together with percentage trapping success.

\begin{tabular}{|c|c|c|c|c|}
\hline $\begin{array}{l}\text { Sampling } \\
\text { date }\end{array}$ & & Bait & & \\
\hline March & $\begin{array}{l}\text { Garri/palm } \\
\text { oil } \\
39.43\end{array}$ & $\begin{array}{l}\text { Whole maize } \\
\text { grains } \\
31.78\end{array}$ & $\begin{array}{l}\text { Ripe } \\
\text { Plantation* } \\
16.25\end{array}$ & $\begin{array}{l}\text { No } \\
\text { bait } \\
14.55\end{array}$ \\
\hline April & $\begin{array}{l}\text { Dried fish } \\
5.95\end{array}$ & $\begin{array}{l}\text { Fresh } \\
\text { coconut } \\
40.75\end{array}$ & $\begin{array}{l}\text { Ripe } \\
\text { banana ** } \\
12.75\end{array}$ & $\begin{array}{c}\text { No } \\
\text { bait } \\
3.10\end{array}$ \\
\hline May & $\begin{array}{l}\text { Fresh } \\
\text { cassava } \\
11.78\end{array}$ & $\begin{array}{l}\text { Roasted } \\
\text { peanuts } \\
14.54\end{array}$ & $\begin{array}{l}\text { Palm fruit } \\
21.48\end{array}$ & $\begin{array}{c}\text { No } \\
\text { bait } \\
3.16\end{array}$ \\
\hline June & $\begin{array}{l}\text { Garri/ } \\
\text { peanut butter } \\
58.22\end{array}$ & $\begin{array}{l}\text { Garri/ } \\
\text { ripe banana } \\
30.68\end{array}$ & $\begin{array}{l}\text { Maize meal/ } \\
\text { peanut butter } \\
58.23\end{array}$ & $\begin{array}{c}\text { No } \\
\text { bait } \\
4.60\end{array}$ \\
\hline July & $\begin{array}{l}\text { Mouse } \\
\text { cubes } \\
45.03\end{array}$ & $\begin{array}{l}\text { Maize meal } \\
\text { ripe banana } \\
35.48\end{array}$ & $\begin{array}{l}\text { Maize meal/ } \\
\text { palm oil } \\
31.58\end{array}$ & $\begin{array}{l}\text { No } \\
\text { bait } \\
13.64\end{array}$ \\
\hline
\end{tabular}

* Musa paradisiaca ** M. sapientum

At the IITA the experimental design used was analogous to the randomized complete block design. A rectangular grid measuring approximately $110 \times 41 \mathrm{~m}$ was set up in the study area. Ten rows of live traps (Havahart No. 0) were set on this grid at distances of 5 paces from one another. There were 25 traps per row, with traps also set 5 paces from one another. Two rows of traps, usually not adjacent to each other, were assigned the same type of bait, so that each treatment was replicated within the grid. This design was adopted in preference to a conpletely randomized model because it is obviously easier to apply the same bait to a single line of traps than to apply it in a random fashion all over the grid. The grid was run for 22 days. Traps were prebaited for six days $(21-26$ Sept. 1977) and then set on five occasions between 27 September and 12 October (Table 5). The position of the baits was randomized on each occasion.

Mice were marked for individual recognition and released at the site of capture. 
The data obtained were analyzed mainly to determine whether there were differences in the trapping success of baits for all species combined, and for particular species. Differences in the response of different sex and age classes were not considered. Trapping success was calculated according to the relation,

$$
C E(\%)=\frac{A \times 100}{(T U-I S / 2)}, \mathrm{Nels} \text { on \& C lark (1973) }
$$

Where $C E=$ catch per 100 trapnights

$A=$ number of mice caught

$T U=$ number of traps units (=no. of traps set $X$ no. of nights traps were set in this study)

$I=$ length of time (in days) between setting and inspection of traps ( $=1$ in this study)

$S=$ total number of traps sprung by mice and by anything else.

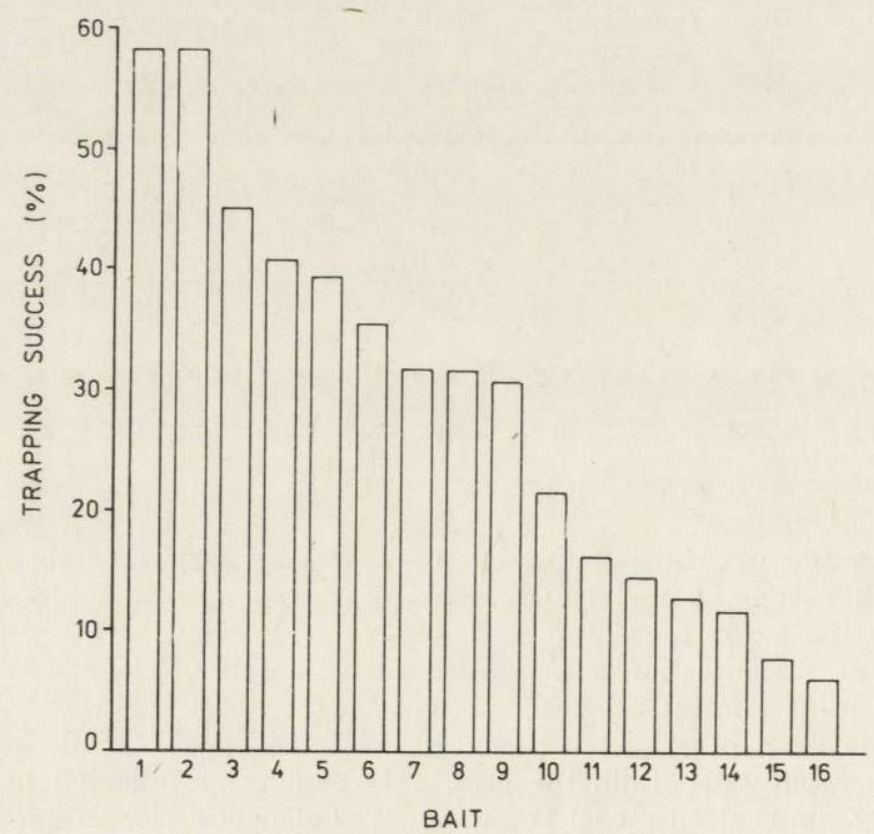

Fig. 1. Trapping success on the grid using various baits (March-July 1976). $1=\mathrm{M}=$ ize meal + Peanut butter; $2=$ Garri (Cassava meal) + Peanut butter; $3=$ Mouse cubes; $4=$ Fresh coconut; $5=$ Garri (Cassava meal) + Palm oil; $6=$ Maize meal + Ripe banana; $7=$ Maize grains (dry); $8=$ Maize meal +Palm oil; $9=$ Garri (Cassava meal) + Ripe banana, $10=$ Palm fruit; $11=$ Ripe plantain; $12=$ Peanuts (Roasted); $13=$ Ripe banana; $14=$ Cassava (Raw); $15=$ Control (No bait); $16=$ Dried fish. 


\subsection{Aje-Pero}

The result of the preliminary trials is summarized in Fig. 1. Seven species of rodents were caught initially, namely; Tatera valida, Praomys (Myomys) daltoni, Mus (Leggada) minutoides, Lemniscomys striatus, Praomys (Mastomys) natalensis, Uranomys ruddi and Graphiurus murinus.

The data suggest that bait made from a mixture of peanut butter and either maize meal or garri (cassava meal) gave the best results, while the least attractive bait was surprisingly dried fish. No detailed analysis or rigid comparisons can be made from these figures because all the baits were not tested against one another. Nevertheless it is noteworthy that baited traps were generally more effective than unbaited traps.

Table 2

Summary of captures of small rodents at Aje-Pero using different baits (Dec. 1976-March 1977).

P.d.-Praomys daltoni, M.m.-Mus minutoides, T.v.-Tatera valida, L.st-Lemniscomys striatus.

\begin{tabular}{|c|c|c|c|c|c|c|c|c|}
\hline \multirow{2}{*}{ Bait } & \multirow{2}{*}{$\begin{array}{l}\text { No. of } \\
\text { trapnights }\end{array}$} & \multicolumn{5}{|c|}{ No. of captures } & \multirow{2}{*}{$\begin{array}{l}\text { No. traps } \\
\text { sprung } \\
\text { but empty }\end{array}$} & \multirow{2}{*}{$\begin{array}{c}\text { Mean } \\
\text { trapping } \\
\text { success, } \%\end{array}$} \\
\hline & & P.d. & M.m. & T.v. & L.s. & Total & & \\
\hline$G P$ & 600 & 8 & 17 & 3 & 0 & 28 & 49 & 25.7 \\
\hline $\mathrm{PN}$ & 600 & 6 & 14 & 1 & 1 & 22 & 54 & 21.4 \\
\hline$G P N$ & 600 & 5 & 16 & 1 & 0 & 22 & 39 & 18.4 \\
\hline$M P N$ & 600 & 6 & 10 & 3 & 0 & 19 & 53 & 17.2 \\
\hline$F C N$ & 600 & 5 & 10 & 5 & 0 & 20 & 31 & 17.0 \\
\hline$M M B$ & 600 & 4 & 13 & 2 & 0 & 19 & 56 & 16.7 \\
\hline MC & 600 & 4 & 11 & 2 & 0 & 17 & 28 & 14.8 \\
\hline$N B$ & 600 & 3 & 2 & 0 & 0 & 5 & 14 & 3.5 \\
\hline Total & 4,800 & 41 & 93 & 17 & 1 & 152 & 324 & \\
\hline
\end{tabular}

Key: $G P=$ Garri + palm oil, $P N=$ Peanut butter, $G P N=$ Garri + peanut butter, $M P N=$ Maize meal + peanut butter, $F C N=$ Fresh coconut, $M M B=$ Maize meal +ripe banana, $M C=$ Mouse cubes, $N B=$ no bait (control).

The result of the second trial using seven baits is presented in Table 2. Only four species of mice, (T. valida, P. daltoni, M. minutoides and L. striatus) were caught this time. Trapping success ranged from $3.5 \%$ (no bait) to $25.7 \%$ (garri+palm oil). Chi-square tests (Table 3 ) showed that while all the mice had a strong preference for baited traps no significant difference could be detected between the success rate of the different baits. This is perhaps not surprising since all the baits were chosen for their high success rate in the preliminary trials. 


\subsection{IITA}

The results of trapping in this locality are presented in Table 4. Only two species of mice, Praomys tullbergi and $M$. minutoides, were caught. An analysis of variance revealed significant treatment differences for the combined result and for $P$. tullbergi, but not for $M$. minutoides (presumably owing to the low catches). When the means were compared

Table 3

Comparison of bait preferences of different small rodents caught af Aje-Pero. *

\begin{tabular}{|c|c|c|c|c|c|c|}
\hline & $G P$ & $P N$ & $G P N$ & $M P N$ & $F C N$ & $M M B$ \\
\hline \multicolumn{7}{|c|}{ 1. All mice combined } \\
\hline$P N$ & 0.500 (NS) & & & & & \\
\hline$G P N$ & 0.500 (NS) & No diff & & & & \\
\hline$M P N$ & 1.361 (NS) & $0.097(\mathrm{NS})$ & $0.097(\mathrm{NS})$ & & & \\
\hline$F C N$ & $1.020(\mathrm{NS})$ & $0.023(\mathrm{NS})$ & $0.023(\mathrm{NS})$ & 0.000 & & \\
\hline$M M B$ & 1.361 (NS) & 0.097 (NS) & $0.097(\mathrm{NS})$ & No diff & 0.000 & \\
\hline$M C$ & $2.222(\mathrm{NS})$ & 0.410 (NS) & 0.041 (NS) & $0.027(\mathrm{NS})$ & 0.108 (NS & $0.027(\mathrm{NS})$ \\
\hline
\end{tabular}

2. P. daltoni

\begin{tabular}{|c|c|c|c|c|c|c|}
\hline$P N$ & $0.071(\mathrm{NS})$ & & & & & \\
\hline$G P N$ & $0.038(\mathrm{NS})$ & 0.000 & & & & \\
\hline$M P N$ & $0.071(\mathrm{NS})$ & No diff & 0.000 & & & \\
\hline$F C N$ & 0.308 (NS) & 0.000 & No diff & 0.000 & & \\
\hline$M M B$ & 0.750 (NS) & 0.100 (NS) & 0.000 & $0.100(\mathrm{NS})$ & 0.000 & \\
\hline$M C$ & 0.750 (NS) & 0.100 (NS) & 0.000 & 0.100 (NS) & 0.000 & No diff \\
\hline
\end{tabular}

3. M. minutoides

\begin{tabular}{|c|c|c|c|c|c|c|}
\hline$P N$ & $0.129(\mathrm{NS})$ & & & & & \\
\hline GPN & 0.000 & $0.333(\mathrm{NS})$ & & & & \\
\hline$M P N$ & $1.332(\mathrm{NS})$ & $0.375(\mathrm{NS})$ & 0.962 (NS) & & & \\
\hline$F C N$ & $1.332(\mathrm{NS})$ & $0.375(\mathrm{NS})$ & $0.962(\mathrm{NS})$ & No diff & & \\
\hline$M M B$ & $0.300(\mathrm{NS})$ & 0.000 & 0.138 (NS) & 0.696 (NS) & $0.696(\mathrm{NS})$ & \\
\hline$M C$ & $0.893(\mathrm{NS})$ & 0.160 (NS) & $0.593(\mathrm{NS})$ & 0.000 & 0.000 & 0.042 (NS) \\
\hline
\end{tabular}

4. T. valida

\begin{tabular}{|c|c|c|c|c|c|c|}
\hline$P N$ & 0.250 (NS) & & & & & \\
\hline$G P N$ & 0.250 (NS) & No diff & & & & \\
\hline$M P N$ & No diff & 0.250 (NS) & 0.250 (NS) & & & \\
\hline$F C N$ & $0.125(\mathrm{NS})$ & 1.500 (NS) & 1.500 (NS) & $0.125(\mathrm{NS})$ & & \\
\hline$M M B$ & 0.000 & 0.000 & 0.000 & 0.000 & $0.571(\mathrm{NS})$ & \\
\hline$M C$ & 0.000 & 0.000 & 0.000 & 0.000 & 0.571 (NS) & No diff \\
\hline
\end{tabular}

NS $=$ not significant at $P=0.05$. Bait symbols as in Table $2 .{ }^{*}$ Trapping success for the single capture of $L$. striatus was not analyzed. 
(Table 5) using Duncan's multiple range test (L it t l e \& H ills, 1972), it was found that:

(1) for both species combined, the trapping success for maize meal+ peanut butter $(M P N)$ was not significantly different from that of fresh coconut $(\mathrm{FCN})$, but that it was significantly different from the success rate of the other baits $(G P N, P N$ and GP). The success rate of $F C N$, on the other hand, did not differ significantly from that of these other baits.

(2) for $P$. tullbergi, there was again no significant difference between $M P N$ and $F C N$; there was also no significant difference between, $F C N$, $G P N$ and $P N$ and again between GPN, $P N$ and GP. But there were significant differences between $M P N$ and GP and between $F C N$ and GP.

\section{DISCUSSION}

In a previous paper ( $\mathrm{A} \mathrm{adu}$, in press) the author reported that certain species of mice living in the derived savanna zone were caught:

Table 4

Summary of captures of small rodents at IITA using diff. baits (27 Sept. - 12 Oct. 1977).

\begin{tabular}{lccccc}
\hline Bait & $\begin{array}{c}\text { No. of } \\
\text { trapnights }\end{array}$ & P. tullbergi & $\begin{array}{c}\text { No. of captures } \\
M . \text { minutoides }\end{array}$ & Total & $\begin{array}{c}\text { No. of traps } \\
\text { sprung but } \\
\text { empty }\end{array}$ \\
\hline MPN & 250 & 55 & 3 & 58 & 90 \\
$F C N$ & 250 & 37 & 2 & 39 & 75 \\
$G P N$ & 250 & 29 & 4 & 33 & 91 \\
$P N$ & 250 & 29 & 2 & 31 & 89 \\
$G P$ & 250 & 16 & 6 & 22 & 76 \\
Total & 1.250 & 166 & 17 & 183 & 421 \\
\hline
\end{tabular}

Bait symbols as in Table-2.

more frequently than others. It was found, for instance, that of the 10 species living in this habitat Mus (Leggada) minutoides and Praomys daltoni made up $85 \%$ of the catch, with Leggada $\left(58^{\circ} \%\right)$ constituting more than one half of the catch. The bait used in this study was a pasty mixture of garri (prepared as "eba") and palm oil. This bait was first used by Dr. Happold (pers. comm.) in his ecological studies of Nigerian small rodents.

Several plausible explanations can be advanced for this observation: either (1) the composition of the catch truly reflected the situation in the habitat, (2) the traps used (Havahart No. 0 and Museum Special) 
were selective, (3) the bait was more attractive to some species than others, or (4) different species became active at different times of the night so that those which became active early in the evening took up most of the traps.

There are strong reasons for rejecting the second and fourth hypotheses. Firstly the second hypothesis; $\mathrm{H}$ a p p old (1975) trapping along a north-south axis in "Western Nigeria" and using the same types of traps observed a gradual change in the composition of his catch from

Table 5

Analysis of bait selection at the IITA (27 Sept. - 12 Oct. 1977).

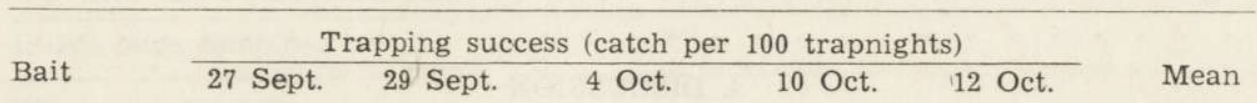

1. Both species combined

\begin{tabular}{lrrrrrr}
\hline$G P$ & 9.8 & 12.0 & 15.4 & 9.0 & 9.6 & $11.2 \mathrm{~b}$ \\
$P N$ & 25.6 & 12.7 & 23.3 & 14.1 & 7.1 & $16.6 \mathrm{~b}$ \\
$M P N$ & 48.6 & 18.4 & 19.4 & 31.2 & 27.4 & $29.0 \mathrm{a}$ \\
$G P N$ & 23.1 & 14.8 & 20.0 & 19.5 & 10.7 & $17.6 \mathrm{~b}$ \\
$F C N$ & 32.1 & 26.0 & 16.1 & 9.3 & 17.5 & $20.2 \mathrm{ab}$ \\
\hline
\end{tabular}

2. P. tullbergi

\begin{tabular}{lrrrrrr}
\hline$G P$ & 7.3 & 7.2 & 12.3 & 6.7 & 7.2 & $8.1 \mathrm{c}$ \\
$P N$ & 25.6 & 12.7 & 20.0 & 11.8 & 7.1 & $15.4 \mathrm{bc}$ \\
$M P N$ & 48.6 & 18.4 & 19.4 & 26.0 & 24.7 & $27.4 \mathrm{a}$ \\
$G P N$ & 17.9 & 9.9 & 20.0 & 19.5 & 10.7 & $15.6 \mathrm{bc}$ \\
$F C N$ & 32.1 & 26.0 & 16.1 & 9.3 & 12.5 & $19.2 \mathrm{ab}$ \\
\hline
\end{tabular}

3. M. minutoides

\begin{tabular}{lllllll}
\hline$G P$ & 2.5 & 4.8 & 3.1 & 2.3 & 2.4 & $3.0 \mathrm{a}$ \\
$P N$ & 0.0 & 0.0 & 3.3 & 2.3 & 0.0 & $1.1 \mathrm{a}$ \\
$M P N$ & 0.0 & 0.0 & 0.0 & 5.2 & 2.7 & $1.6 \mathrm{a}$ \\
$G P N$ & 5.2 & 4.9 & 0.0 & 0.0 & 0.0 & $2.0 \mathrm{a}$ \\
$F C N$ & 0.0 & 0.0 & 0.0 & 0.0 & 5.0 & $1.0 \mathrm{a}$ \\
\hline
\end{tabular}

a, b, c: Means followed by the same suffix are not significantly different at the $5 \%$ level. Bait symbols as in Table 2 .

south to north. Thus he noted that $M$. minutoides was the dominant small mammal in the grassland community near the forest edge; in the southern guinea savanna (and on inselbergs) $P$. daltoni became the commonest species while in the northern guinea savanna it was replaced by $T$. valida.

The fourth explanation is considered unlikely because observations made by the author at Aje-Pero (Table 6) suggest that trap competition as a result of differences in activity pattern was not an important source 
of bias. When traps were inspected twice every night during fortnightly visits (from 27 December 1976 to 3 June 1977) it was found that the three commonest species, $T$. valida, $P$. daltoni and $M$. minutoides were more active between 10 p.m. and dawn than they were in the early evening. It is, of course quite possible that more closely spaced inspection of traps (say every $2 \mathrm{hr}$.) may reveal different peaks of activity for each species between 10 p.m. and dawn, but the presence of a substantial number of unoccupied traps every morning suggests that not many mice were turned away because of a shortage of traps.

The present investigation was therefore designed to test the third hypothesis, and the results (Table $2 \& 3$ ) suggest that all the seven baits tested together were equally attractive to the three rodents that were trapped frequently. Furthermore, each bait caught more $M$. minutoides than $P$. daltoni and more $P$. daltoni than $T$. valida. It is therefore reasonable to assume that the composition of the catch reflected the relative abundance of each species in this habitat.

It is however interesting that in the forest zone, P. tullbergi, which is the commonest species in this habitat ( $\mathrm{H}$ a p pold, 1975), showed a definite preference for certain baits, and that the garri/palm oil mixture which recorded the highest trapping success in the savanna zone (Table 2) was the least attractive. Unfortunately, the locality

Table 6

Activity pattern of small rodents in the derived savanna zone (Aje-Pero, 27 Dec. 1976 - 3 June 1977).

\begin{tabular}{|c|c|c|c|c|}
\hline \multirow[b]{2}{*}{ Species } & \multicolumn{2}{|c|}{ Number caught } & \multirow[b]{2}{*}{ Total } & \multirow[b]{2}{*}{$\chi^{2}$} \\
\hline & Before $10 \mathrm{pm}$ & After $10 \mathrm{pm}$ & & \\
\hline Tatera valida & 3 & 13 & 16 & $5.06^{*}$ \\
\hline Taterillus qracilis & 0 & 1 & $1+$ & \\
\hline Praom?s daltoni & 3 & 21 & 24 & $12.04^{* *}$ \\
\hline Mus minutoides & 8 & 49 & 57 & $28.04^{* *}$ \\
\hline Total & 14 & 84 & 98 & \\
\hline
\end{tabular}

* Significant at the $5 \%$ level.

** Significant at the $1 \%$ level.

$+=$ The single capture of $T$. gracilis is not analyzed.

sampled (IITA) was not rich in species diversity. It was therefore impossible to determine the bait preference of the other forest rodents, and consequently, to what extent this factor would affect the results of trapping in this biome if a single bait is used (e.g. $\mathrm{H} \mathrm{a} \mathrm{p} \mathrm{pold,} \mathrm{1975).}$

It is not clear what makes a bait attractive to rodents. Pirlot \& Van den Bulcke (1952) thought that taste was more important than smell. N e a l (1967) disagreed with this suggestion. He thought smell 
was more important because he found that two commonly trapped species of Mus (M. triton and M. minutoides) rarely ate the bait in his traps. This conclusion is not surprising though, because it is doubtful whether the putrid mixture of maize meal/banana which he used would have been found tasty by any mouse. However, there is good a priori reason to believe that smell could be more important than taste. A small mammal foraging under dense vegetation cover and/or in the dark is more likely to rely heavily on its sense of smell and hearing in finding its way than on anything else. In the circumstance, it is the only way it can survey its surrounding from a safe distance. Mice possess an acute sense of smell, and have the well-known habit of sniffing our their surrounding thoroughly during exploratory behaviour. Thus, it seems certain that a baits is first located by smell and is subsequently eaten if found palatable. All the baits tested had some kind of smell (although differences in olfactory accuity between men and mice make objective comparisons difficult) and quite often all the bait placed in a trap was eaten by a captive mouse.

In view of its acceptance by the forest and savanna rodents caught during this study, it is suggested that fresh coconut would be a good "all purpose « bait. It was used apparently with great success, by $\mathrm{T}$ amarin \& M a lecha $(1971,1972)$ in Hawaii, and has the following advantages over the other baits tested in this study: (1) it will not be washed away or made soggy by the rain, (2) it is less attractive to ants than oily baits and (3) it is easier to prepare, carry around and apply to traps (especially break - backs).

Acknowledgements: This study was made possible by a grant from the Senate Research Grants Subcommittee of the University of Ibadan, and the Population Dynamics Programme of the University of Ghana, Legon. The author wishes to acknowledge the generosity of both sources. I am also indebted to Professor M. A. O. Soyannwo for permission to trap in his ranch at Aje-Pero, and to the Director of the International Institute for Tropical Agriculture Ibadan, for permission to trap inside the institute.

\section{REFERENCES}

1. A dams L. \& Davis S. D., 1967: The internal anatomy of home range. J. Mamm., 48: 529-536.

2. Anadu P. A. (in press): The small rodents of the derived savanna zone south-western Nigeria (with notes on the shrews).

3. Dela ny M. J., 1964: A study of the ecology and breeding of small mammals in Uganda. Proc. zool. Soc., Lond., 152: 347-370.

4. Delany M. J. 1971. The biology of small rodents in the Mayanja Forest, Uganda. J. Zool., Lond., 165: 85-129.

5. Hanney P., 1965: The Muridae of Malawi (Africa: Nyasaland). J. Zool., Lond., 146: $577-633$. 
6. Happold D. C. D., 1966: The mammals of Jebel Marra, Sudan. J. Zool., Lond., 149: 126-136.

7. Happold D. C. D., 1975: The effects of climate and vegetation on the distribution of small rodents in Western Nigeria. Z. Säugetierkunde, 40: 221242.

8. Little T. M. \& Hills F. J., 1972: Statistical Methods in Agricultural Research. University of California: 1-242. Davis.

9. Meester J. \& Setzer H. W. (Eds), 1971-77: The mammals of Africa. An indentification manual. Smithsonian Inst. Press, Washington.

10. Neal B. R., 1967: The ecology of small rodents in the grassland community of the Queen Elizabeth National Park, Uganda. Ph. D. thesis, University of Southampton.

11. Ne 2.1 B. R. \& Cock A. G., 1969: An analysis of the selection of small African mammals by two break-black traps. J. Zool., Lond., 158: 335-340.

12. Neal B. R. \& Clark F. W., 1973: Correction for sprung traps in catch/ effort calculations of trapping results. J. Mamm., 54: 295-298.

13. Pirlot P. L. \& Blucke M. van den, 1952: Piegeages de Rongeurs dans le Haut-Katanga (Congo Belge). Rev. Zool. Bot. afr., 46: 184-209.

14. T a marin R. H. \& $\mathrm{Male} c \mathrm{~h}$ a S. R., 1971: The population biology of $\mathrm{Ha}-$ waiian rodents: Demographic parameters. Ecology, 52: 383-394.

15. T a marin R. H. \& M a le c ha S. R., 1972: Reproductive parameters in Rattus ratius and Rattus exulans of Hawaii, 1966 to 1970. J. Mamm., 53: 513-528.

Accepted, April 30, 1979.

P. A. ANADU

\section{WP£YW RODZAJU PRZYNETY \\ NA ODÆOW DROBNYCH SSAKOW AFRYKAŃSKICH}

Streszczenie

Badano efektywność wyłowu przy pomocy pułapek z przynętą i bez przynęty a także działanie kilku rodzajów przynęt, którymi były lokalnie dostępne artykuły żywnościowe (Tabele 1, 2). Pułapki z przynętą łowią istotnie więcej myszy niż bez przynęty (Tabele 3,4). Spośród 15 wstępnie wypróbowanych przynęt wybrano siedem i testowano działanie na wyłów gryzoni żyjących na sawannie. Stwierdzono, że najczęściej łowione gatunki Tatera valida, Praomys (Myomys) daltoni i Mus minutoides nie wykazują wyraźnej preferencji w stosunku do którejś z nich (Tabela 6; Ryc. 1). Pięć z tych przynẹt testowano w zbiorowiskach leśnych i stwierdzono, że mączka kukurydziana $\mathrm{z}$ olejem arachidowym i świeże orzechy kokosowe były najefektywniejszą przynętą w łowieniu pospolitego gatunku Praomys tullbergi (Tabela 5). Na podstawie wniosków wypływających z tych badań autora sugeruje, że świeże orzechy kokosowe mogą stanowić "uniwersalną" przynętę stosowaną $w$ odłowach drobnych gryzoni zamieszkujących lasy i sawanny. 